\title{
Clinical aspects of a nationwide epidemic of severe haemolytic uremic syndrome (HUS) in children
}

\author{
Lars Krogvold ${ }^{1 *}$, Thore Henrichsen ${ }^{1}$, Anna Bjerre ${ }^{2}$, Damien Brackman ${ }^{3}$, Henrik Dollner ${ }^{4}$, Helga Gudmundsdottir ${ }^{5}$, \\ Gaute Syversen ${ }^{6}$, Pål Aksel Næss ${ }^{7}$ and Hans Jacob Bangstad ${ }^{1}$
}

\begin{abstract}
Background: Report a nationwide epidemic of Shiga toxin-producing E. coli (STEC) O103:H25 causing hemolytic uremic syndrome (D+HUS) in children.

Methods: Description of clinical presentation, complications and outcome in a nationwide outbreak.

Results: Ten children (median age 4.3 years) developed HUS during the outbreak. One of these was presumed to be a part of the outbreak without microbiological proof. Eight of the patients were oligoanuric and in need of dialysis. Median need for dialysis was 15 days; one girl did not regain renal function and received a kidney transplant. Four patients had seizures and/or reduced consciousness. Cerebral oedema and herniation caused the death of a 4-year-old boy. Two patients developed necrosis of colon with perforation and one of them developed non-autoimmune diabetes.

Conclusion: This outbreak of STEC was characterized by a high incidence of HUS among the infected children, and many developed severe renal disease and extrarenal complications. A likely explanation is that the O103:H25 (eae and stx $x_{2}$-positive) strain was highly pathogen, and we suggest that this serotype should be looked for in patients with HUS caused by STEC, especially in severe forms or outbreaks.
\end{abstract}

\section{Background}

Haemolytic uremic syndrome (HUS) is a severe, acute and dramatic disease affecting previously healthy children. HUS is defined as a triad of acute kidney injury, microangiopatic haemolytic anaemia and thrombocytopenia in patients with no other explanation for coagulopathy [1] e.g. thrombotic thrombocytopenic purpura. More than $90 \%$ of the cases are due to Shiga toxin-producing E. coli (STEC) infections; termed typical HUS or diarrhoea associated HUS (D+HUS). Many different serotypes can cause HUS, the most prevalent in Europe and USA being O157:H7 [2,3]. A broad spectrum of extrarenal complications may occur in HUS, the most common are gastrointestinal and cerebral. Extrarenal involvement at an early stage is associated with increased morbidity

\footnotetext{
* Correspondence: lars.krogvold@medisin.uio.no

'Department of Paediatrics, Oslo University hospital, Ulleval, Kirkeveien 166, 0407 Oslo, Norway

Full list of author information is available at the end of the article
}

and mortality. Although several epidemics, caused by O157 [4] and other serotypes [5] have been reported, the majority of HUS cases appear sporadic or in small clusters [1].

In 2006 a nationwide outbreak of STEC-infections took place in Norway. Totally 17 cases (16 children and one adult) were identified during the outbreak, all caused by a rare variant $\left(\mathrm{O} 103: \mathrm{H} 3\right.$, eae and $s t x_{2}$-positive). Some microbiological, serological and epidemiological aspects of the outbreak have previously been reported [6,7]. In this article we will focus on those children that presented with typical HUS since the clinical course was characterized by an aggressive disease with significant extrarenal complications.

\section{Methods}

Within a short period of time from $30^{\text {th }}$ of January to $13^{\text {th }}$ of March 2006 a nationwide outbreak of STEC -infections occurred. As soon as the epidemic pattern

\section{Biomed Central}


was confirmed, health personnel were informed by the National health authorities, and instructed to collect faecal samples on all suspected cases with possible HUSrelated $E$. coli infection (diarrhoea and fever). At the same time microbiological laboratories were instructed to investigate specifically for serotype O103.

Clinical data of the children were retrieved from medical notes and charts. All five university-hospitals in Norway treating children with HUS were contacted, and a review of all admissions were done at each department to ensure all cases being included

\section{Results}

Sixteen children were infected by E. coli O103:H25 during the outbreak. Ten of these children (six girls and four boys), with a median age of 4.3 years (range 1.8-8.5), were admitted to hospital with the clinical picture of typical D+ HUS and constitute our study population. The children were living widely spread, and were admitted to the department of paediatrics at four different University Hospitals with a median time of symptoms of 5 days (range 2-10).

\section{Presentation on admission}

Eight of the ten children were severely affected with bloody diarrhoea when admitted to hospital. Eight patients were oligoanuric with urine output less than 0.5 $\mathrm{mL} / \mathrm{kg} / \mathrm{h}$. Elevated serum creatinine, leukocytosis, thrombocytopenia, elevated lactate dehydrogenase (LD) and hyponatremia (nine out of ten) were common findings (Table 1). The haemoglobin values on admission varied, but all patients developed marked haemolytic anaemia during their first week in hospital and received blood transfusion, the indication being respiratory compromise or severe anaemia (Table 1).

\section{Renal complications and outcome}

Eight patients required dialysis (Table 2). Haemodialysis was chosen in four children, in three cases based on the severity of abdominal pain and activity of enterocolitis and in one case due to recent abdominal surgery. Peritoneal dialysis was chosen in four children with less severe abdominal symptoms on admission. However, in two of these patients intestinal perforation occurred and peritoneal dialysis were therefore switched to haemodialysis. The median time on dialysis was 15 days (3 days $>1$ year), or 14 days (3-34 days) excluded the patient who developed ESRF and later had a kidney transplant. On follow up one year after diagnosis, four patients had regained normal renal function and normal blood pressure, and four patients had low-grade proteinuria and/or microscopic haematuria, but no hypertension, defined as blood-pressure above the $95^{\text {th }}$ percentile for age, sex and height. Patient number 9 developed end stage renal failure and was on dialysis until she received a living related kidney transplant 12 months after her first symptoms.

\section{Extrarenal complications}

Five of the children had signs of CNS involvement (Table 2). One boy died three days after admission of cerebral herniation. Cerebral magnetic resonance imaging (MRI) showed generalised oedema and bilateral infarcts in the basal gangliae. Four patients presented cerebral seizures and/or reduced consciousness (Table 2 ). One of these had a unilateral infarction in the area of putamen on cerebral MRI. He recovered and neurological examination on discharge was completely normal. The other patients with cerebral symptoms had normal MRI-findings.

Table 1 Laboratory values for ten patients with HUS caused by E. coli 0103:H25

\begin{tabular}{|c|c|c|c|c|c|c|c|c|c|c|}
\hline \multirow{3}{*}{$\frac{\text { Patient }}{\text { No }}$} & \multirow{2}{*}{\multicolumn{2}{|c|}{$\begin{array}{c}\text { Haemoglobin } \\
(g / d L)\end{array}$}} & \multirow{2}{*}{\multicolumn{2}{|c|}{$\frac{\text { Creatinine }}{(\mu \mathrm{mol} / \mathrm{L})}$}} & \multirow{2}{*}{\multicolumn{2}{|c|}{$\begin{array}{c}\text { Lactate dehydrogenase } \\
(\mathrm{U} / \mathrm{L})\end{array}$}} & \multirow{2}{*}{\multicolumn{2}{|c|}{$\begin{array}{c}\text { Thrombocytes } \\
\left(\times 10^{9} / \mathrm{L}\right)\end{array}$}} & \multirow{3}{*}{$\begin{array}{c}\text { Leucocytes } \\
\left(\times 10^{9} / \mathrm{L}\right) \\
\text { Admission }\end{array}$} & \multirow{3}{*}{$\begin{array}{c}\text { Sodium } \\
\text { (mmol/L) } \\
\text { Admission }\end{array}$} \\
\hline & & & & & & & & & & \\
\hline & Admission & Min. & Admission & Max. & Admission & Max. & Admission & Min. & & \\
\hline 1 & 7.6 & 5.7 & 461 & 492 & 2888 & 2888 & 43 & 29 & 9.1 & 132 \\
\hline 2 & 9.3 & 7.7. & 82 & 162 & 2241 & 3575 & 17 & 16 & 7.1 & 137 \\
\hline 3 & 11.5 & 7.5 & 196 & 407 & 3888 & 3888 & 84 & 62 & 33.8 & 128 \\
\hline 4 & 11.2 & 6.5 & 231 & 358 & 3827 & 4287 & 41 & 41 & 16.5 & 132 \\
\hline 5 & 9.5 & 7.6 & 627 & 673 & 3803 & 3803 & 61 & 23 & 33.7 & 133 \\
\hline 6 & 9.1 & 7.1 & 421 & 658 & 4036 & 4036 & 60 & 60 & 21.0 & 127 \\
\hline 7 & 12.2 & 5.5 & 143 & 422 & 764 & 3212 & 134 & 67 & 30.0 & 132 \\
\hline 8 & 16.9 & 8.8 & 107 & 276 & 2641 & 3431 & 61 & 35 & 41.3 & 121 \\
\hline 9 & 12.5 & 7.6 & 153 & 405 & 2419 & 2928 & 110 & 66 & 35.3 & 127 \\
\hline 10 & 6.1 & 5.4 & 84 & 84 & 2566 & 2566 & 109 & 107 & 25.4 & 125 \\
\hline Median & 10.4 & 7.3 & 175 & 406 & 2764 & 3503 & 61 & 51 & 27.7 & 130 \\
\hline
\end{tabular}

HUS: Haemolytic uremic syndrome 
Table 2 Mode of dialysis, acute symptoms and complications in ten patients with D+HUS caused by E. coli $0103: \mathrm{H} 25$

\begin{tabular}{|c|c|c|c|c|c|c|}
\hline \multirow{2}{*}{$\begin{array}{c}\text { Patient } \\
\text { No }\end{array}$} & \multirow{2}{*}{\multicolumn{2}{|c|}{$\begin{array}{c}\text { Dialysis } \\
\text { Mode }\end{array}$}} & \multicolumn{2}{|r|}{ Neurological } & \multirow[t]{2}{*}{ Gastrointestinal } & \multirow[t]{2}{*}{ Others } \\
\hline & & & Symptoms & $\mathrm{MRI} / \mathrm{CT}$ & & \\
\hline & \multicolumn{2}{|c|}{$\begin{array}{l}\text { Duration } \\
\text { (Days) }\end{array}$} & & & & \\
\hline 1 & $\mathrm{HD}$ & 7 & - & - & - & - \\
\hline 2 & - & - & - & - & - & - \\
\hline 3 & PD & 15 & Reduced consciousness & MRI: Infarction basal ganglia & - & - \\
\hline 4 & $\begin{array}{l}\mathrm{PD} / \\
\mathrm{HD}\end{array}$ & 15 & - & - & Perforation of colon & - \\
\hline 5 & $\mathrm{HD}$ & 13 & Reduced consciousness & $\mathrm{CT}$ normal & - & - \\
\hline 6 & PD & 34 & $\begin{array}{l}\text { Generalised seizures before } \\
\text { admission }\end{array}$ & MRI normal (8 months after) & - & - \\
\hline 7 & $\mathrm{HD}$ & 14 & - & - & $\begin{array}{l}\text { Laparoscopy: suspect } \\
\text { appendicitis }\end{array}$ & $\begin{array}{l}\text { Insulin for } 5 \\
\text { days }\end{array}$ \\
\hline 8 & $\mathrm{HD}$ & 3 & $\begin{array}{l}\text { Death due to fatal cerebral } \\
\text { oedema }\end{array}$ & $\begin{array}{c}\text { CT/MRI: generalised oedema, infarction of } \\
\text { basal ganglia }\end{array}$ & - & - \\
\hline 9 & $\begin{array}{l}\mathrm{PD} / \\
\mathrm{HD}^{*}\end{array}$ & $\infty$ & $\begin{array}{l}\text { Reduced consciousness and } \\
\text { seizures }\end{array}$ & CT/MRI normal & Colon necrosis & $\begin{array}{l}\text { Diabetes } \\
\text { mellitus }\end{array}$ \\
\hline 10 & - & - & - & - & - & - \\
\hline
\end{tabular}

*Switched to HD because of intestinal perforation

HUS: Haemolytic uremic syndrome

MRI: magnetic resonance imaging

$\mathrm{CT}$ : Computer tomography

HD: haemodialysis

PD: Peritoneal dialysis.

Appendectomy was performed in one girl in a local hospital before the HUS diagnosis was established. The removed appendix was not inflamed. Two patients developed necrosis of colon with perforation and underwent laparotomy on hospital day 6 (left hemicolectomy) and day 24 (subtotal colectomy), respectively. One patient developed permanent insulin dependent diabetes mellitus with negative anti-GAD antibodies, and another had transient hyperglycaemia with the need of insulininfusion for five days.

\section{Antibiotics}

Seven patients were treated with antibiotics. In patient 6 antibiotics was started at the local hospital because of suspected sepsis 6 hours prior to the diagnosis of HUS, although presenting with bloody stools, anuria and thrombocytopenia (Table 1). The remaining six children who received systemic antibiotics, all started treatment at least three days after the diagnosis of HUS was established. In three children (patients 3, 4 and 9) antibiotics were administered in the peritoneal dialysis fluid on the assumption of peritonitis. Bacterial cultures were later proven negative. Five patients were given antibiotics intravenously, for suspected sepsis (patient 2, 8 and 9), perforation of colon (patient 4 and 9) or catheter related infection (patient 5), respectively.

\section{Microbiology}

In eight of ten patients who developed HUS, specific IgG antibodies against O103 were detected. In four of the patients, O103:H25 was found in faecal samples. The bacteria were also found in faecal samples from six children who did not develop HUS. In one boy (patient 1) faecal samples could not be collected, and IgG antibodies against $\mathrm{O} 103$ were not detected. We have included this patient in the report based on the fact that he had eaten the specific smoked sausage and was the first reported case in the outbreak [6].

\section{Discussion}

We present a nationwide outbreak of STEC causing severe HUS in a high percentage of the affected children. The clinical course was characterized by an aggressive disease with significant extrarenal complications. In Norway there are five University Hospitals with paediatric departments, all in close contact with the local paediatric departments. Due to the alert of the outbreak, the University Hospitals were contacted to treat all cases of HUS. The affected children were admitted to four of these departments, the $5^{\text {th }}$ department confirming that no patient with HUS was admitted during the outbreak. Therefore we conclude our material includes all the affected children. 
Several clinical and biochemical features at onset of HUS have been proposed to be related to poor prognosis [8]. Among the most often proposed factors are leukocytosis and anuria [9-11]. A case-control study from 2006 dealt with 17 deaths among patients with HUS and concluded that those presenting with oligoanuria, dehydration, WBC $>20 \times 10^{9} / \mathrm{L}$ and haematocrit $>23 \%$ are at substantial risk of fatal HUS [12]. Most of the patients in our material (seven of 10) had white blood count above $20 \times 10^{9} / \mathrm{L}$ on admission; the highest level $\left(41.3 \times 10^{9} / \mathrm{L}\right)$ was registered in the boy who died. He also had the highest haemoglobin-level and thereby haematocrit, corresponding well with the risk-factors pointed out by Oakes et al. [12]. Eight of ten patients were oligoanuric on admission.

Seven of the children needed transient dialysis, with a median duration of 15 days. One patient developed end stage renal failure and received a living related kidney transplant one year later. According to the literature, around half of children with HUS will need dialysis, with a median duration of 5 to 7 days [13]. This epidemic shows a higher proportion of patients developing a very severe disease with extrarenal complications.

CNS involvement is common and is reported in 20$50 \%$ of HUS cases $[14,15]$ and was present in five patients in our material. Common signs of CNS involvement in HUS are seizures, reduced level of consciousness, hemiparesis, visual disturbances and brain stem symptoms. Basal ganglia involvement is a typical MRIfinding in HUS-patients with neurological complications [15], and was present in two of our patients (Table 2).

The reported incidence of colon necrosis and perforation in case studies varies from 1-8\% [16-19]. A review by Siegler in 1994 reported a total incidence of colon necrosis/perforation at 2\% [14]. Two of the patients in the present study developed necrosis of colon (20\%). Patient 9 underwent subtotal colectomy 27 days after onset of symptoms. In a paper reviewing the occurrence of colonic necrosis in patients with HUS, a mean of 11 days after onset of symptoms was reported [18]. Both our patients were on peritoneal dialysis when the necrosis occurred. To our knowledge peritoneal dialysis being a risk factor for the development of colonic necrosis in patients with HUS has not been reported. However, peritoneal dialysis may mask abdominal symptoms leading to delay in diagnosis and surgical treatment.

Diabetes mellitus is a rare complication of HUS and mainly occurs in severe cases [19]. A systematic review of 21 studies concluded a pooled incidence of 3.2\% [20]. Autopsy studies have shown thrombosis of the vessels supplying the islets of Langerhans with preservation of the exocrine pancreas [21]. One girl (patient 9) developed permanent insulin-dependent diabetes mellitus. There was no evidence of autoimmune diabetes as all diabetes related autoantibodies were negative. She was seriously ill on admission and developed necrosis of colon and end stage renal failure, and finally received a kidney transplant. This corresponds to a previous review, stating that children with HUS who develop diabetes mellitus, were more likely to have severe disease with increased mortality risk [20]. Among survivors, $38 \%$ were left with permanent diabetes requiring insulin [20]. Even though this patient also needed a kidney transplant, simultaneous pancreas and kidney transplantation was not an option, due to our policy to use living related donors which favourably influence outcome.

All children received blood transfusions. The mean haemoglobin-value at transfusion was $6.9 \mathrm{~g} / \mathrm{dL}$. Erythrocyte transfusions in HUS should be avoided if possible, and some suggest it is indicated only when haemoglobin is below $6.0 \mathrm{~g} / \mathrm{dL}$ [22]. Nevertheless, the usual indications for erythrocyte transfusions apply, i.e. respiratory compromise and cerebral involvement, and $70-80 \%$ of patients with HUS will require transfusions [1,23].

Antibiotics is contraindicated in the treatment of possible STEC infections, due to increased toxin-release from bacterial lysis [24] or increased production of toxin due to induction of bacteriophages on which stxgenes are located [25]. In our material, six children received intravenous antibiotics. However, the treatment was initiated after the diagnosis of HUS was established in five, and none of the patients had antibiotics started as treatment of HUS, but on the suspicion of secondary bacterial infections.

To our knowledge this is the first outbreak of HUS caused by E. coli O103. The microbiological, serological and epidemiological aspects of the outbreak have previously been published [6,7]. We found positive faecal samples for O103:H25 in ten children during the outbreak, and four of these developed HUS. This high incidence of HUS among the infected patients contrasts previous reports on E. coli O157:H7 outbreaks, in which 11\%-14\% developed HUS [26,27]. During the present outbreak, the attention-level in the population was kept high due to huge interest of the epidemic in the media. National health authorities instructed parents to see a physician if their child had any symptoms of diarrhoea or vomiting. Physicians were informed by the Norwegian Institute of Public Health to collect faecal samples from children with diarrhoea and the number of faecal samples analyzed by the microbiological laboratories increased. On that background it is unlikely that the number of children infected by this specific O103-strain was substantially higher than those diagnosed. The specific diagnosis of O103 was confirmed either through faecal sampling or serology in nine out of ten patients. This corresponds to Lynn et al. who found that $84 \%$ of the cases of HUS in UK and Ireland in 1997-2001 were 
similarly confirmed [2]. In the present report positive faecal samples were found in only four of the patients with HUS. The explanation to this might partially be due to difficulties collecting adequate samples; several of the children did not pass stool for several days after admission to hospital. In a prospective surveillance of Canadian children with HUS from 2000 to 2002, stool cultures showed evidence of bacterial pathogens in $67 \%$ of the patients, but only two non-O157-strains were found [28].

\section{Conclusion}

This outbreak of colitis caused by STEC serotype O103: $\mathrm{H} 25$ (eae and $s t x_{2}$-positive) was characterized by a very high incidence of HUS, and the majority of the affected children experienced severe renal disease and significant extrarenal complications. Although genetic variability theoretically could explain Norwegian children being more prone to severe disease, we suggest that STEC serotype O103:H25 (eae and $s t x_{2}$-positive) may be highly pathogenic and should be investigated for in future HUS outbreaks.

\section{List of abbreviations}

HUS: haemolytic uremic syndrome; D+: diarrhoea associated; STEC: shigatoxin-producing E. Coli; EHEC: enterohaemorrhagic E. Coli; LD: lactate dehydrogenase; MRI: magnetic resonance imaging; stx: shigatoxin; WBC: white blood cells.

\section{Acknowledgements}

The authors thank the families involved in this outbreak. The authors disclose no financial agreement and no conflict of interest to this article.

\section{Author details \\ 'Department of Paediatrics, Oslo University hospital, Ulleval, Kirkeveien 166, 0407 Oslo, Norway. ${ }^{2}$ Department of Paediatrics, Section for Specialised Medicine, Oslo University Hospital, Rikshospitalet, Norway. ${ }^{3}$ Department of Paediatrics, Haukeland Hospital, Bergen, Norway. ${ }^{4}$ Children's Department, St. Olavs University Hospital of Trondheim, Institute of Laboratory Medicine, Children's and Women's Health, Norwegian University of Science and Technology, Trondheim, Norway. ${ }^{5}$ Nephrological Department, Oslo University Hospital, Ulleval, Norway. ${ }^{6}$ Department of Microbiology, Oslo University Hospital, Ulleval, Norway. ${ }^{7}$ Department of Paediatric Surgery, Oslo University Hospital, Ulleval, Norway}

\section{Authors' contributions}

All authors have read and approved the final manuscript. LK contributed during all steps in designing and producing this report, coordinated the author team, been involved in the treatment in most of the patients, and controlled data sampling and -analysis. TH was deeply involved in the medical treatment of $50 \%$ of the patient included in this report, contributed essentially to the writing of the manuscript, and reviewed current literature. $A B, D B, H D$ took medical care of $50 \%$ of the patients, participated in designing the report, provided data, contributed to analyzing the data and reviewed critically the manuscript in all stages of the process. HG performed dialysis in patients with HUS, reviewed up to date literature in the field of treatment of HUS, reviewed data and read all versions of the manuscript and gave comments on all sections of the manuscript, especially to the discussion. GS contributed with knowledge and competence in detecting and analysing microbiological data controlled all microbiological data and outlined the section "methods" and contributed to the description of the microbiological results and the discussion. PAN was involved in the surgical treatment of many of the patients included, contributed essentially to the writing of the manuscript. HJB is the supervisor of the first author, and contributed in all parts in the process of making this article.

\section{Competing interests}

The authors declare that they have no competing interests.

Received: 11 April 2011 Accepted: 28 July 2011 Published: 28 July 2011

\section{References}

1. Tarr PI, Gordon CA, Chandler WL: Shiga-toxin-producing Escherichia coli and haemolytic uraemic syndrome. Lancet 2005, 365:1073-1086.

2. Lynn RM, O'Brien SJ, Taylor CM, Adak GK, Chart H, Cheasty T, Coia JE, Gillespie IA, Locking ME, Reilly WJ, Smith HR, Waters A, Willshae GA: Childhood hemolytic uremic syndrome, United Kingdom and Ireland. Emerg Infect Dis 2005, 11:590-596.

3. Banatvala N, Griffin PM, Greene KD, Barrett TJ, Bibb WF, Green JH, Wells JG: The United States National Prospective Hemolytic Uremic Syndrome Study: microbiologic, serologic, clinical, and epidemiologic findings. $J$ Infect Dis 2001, 183:1063-1070.

4. Bell BP, Goldoft M, Griffin PM, Davis MA, Gordon DC, Tarr PI, Bartleson CA, Lewis JH, Barrett TJ, Wells JG, Baron R, Kobayashi J: A multistate outbreak of Escherichia coli 0157:H7-associated bloody diarrhea and hemolytic uremic syndrome from hamburgers. The Washington experience. JAMA 1994, 272:1349-1353.

5. Brooks JT, Sowers EG, Wells JG, Greene KD, Griffin PM, Hoekstra RM, Strockbine NA: Non-0157 Shiga toxin-producing Escherichia coli infections in the United States, 1983-2002. J Infect Dis 2005, 192:1422-1429.

6. Schimmer B, Nygard K, Eriksen HM, Lassen J, Lindstedt BA, Brandal LT, Kapperud G, Aavitsland P: Outbreak of haemolytic uraemic syndrome in Norway caused by stx2-positive Escherichia coli 0103:H25 traced to cured mutton sausages. BMC Infect Dis 2008, 8:41.

7. Sekse C, Muniesa M, Wasteson Y: Conserved Stx2 phages from Escherichia coli 0103:H25 isolated from patients suffering from hemolytic uremic syndrome. Foodborne Pathog Dis 2008, 5:801-810.

8. Gianviti A, Tozzi AE, De PL, Caprioli A, Rava L, Edefonti A, Ardissino G, Montini G, Zacchello G, Ferretti A, Pecoraro C, De Palo T, Caringella A, Gaido M, Coppo R, Perumo F, Miglietti N, Ratsche I, Penza R, Capasso G, Maringhini S, Li Volti S, Setzu C, Pennesi M, Bettinelli A, Peratoner L, Pela I, Salvaggio E, Lama G, Maffei S, Rizzoni G: Risk factors for poor renal prognosis in children with hemolytic uremic syndrome. Pediatr Nephrol 2003, 18:1229-1235.

9. Malla K, Malla T, Hanif M: Prognostic indicators in haemolytic uraemic syndrome. Kathmandu Univ Med J (KUMJ) 2004, 2:291-296.

10. Siegler RL, Pavia AT, Christofferson RD, Milligan MK: A 20-year populationbased study of postdiarrheal hemolytic uremic syndrome in Utah. Pediatrics 1994, 94:35-40.

11. Green DA, Murphy WG, Uttley WS: Haemolytic uraemic syndrome: prognostic factors. Clin Lab Haematol 2000, 22:11-14.

12. Oakes RS, Siegler RL, McReynolds MA, Pysher T, Pavia AT: Predictors of fatality in postdiarrheal hemolytic uremic syndrome. Pediatrics 2006, 117:1656-1662.

13. Siegler R, Oakes R: Hemolytic uremic syndrome; pathogenesis, treatment, and outcome. Curr Opin Pediatr 2005, 17:200-204.

14. Siegler RL: Spectrum of extrarenal involvement in postdiarrheal hemolytic-uremic syndrome. J Pediatr 1994, 125:511-518.

15. Steinborn M, Leiz S, Rudisser $\mathrm{K}$, Griebel M, Harder T, Hahn H: CT and MRI in haemolytic uraemic syndrome with central nervous system involvement: distribution of lesions and prognostic value of imaging findings. Pediatr Radiol 2004, 34:805-810.

16. Crabbe DC, Broklebank JT, Spicer RD: Gastrointestinal complications of the haemolytic uraemic syndrome. J R Soc Med 1990, 83:773-775.

17. Tapper D, Tarr P, Avner E, Brandt J, Waldhausen J: Lessons learned in the management of hemolytic uremic syndrome in children. J Pediatr Surg 1995, 30:158-163.

18. Saltzman DA, Chavers B, Brennom W, Vernier R, Telander RL: Timing of colonic necrosis in hemolytic uremic syndrome. Pediatr Surg Int 1998, 13:268-270.

19. Grodinsky S, Telmesani A, Robson WL, Fick G, Scott RB: Gastrointestinal manifestations of hemolytic uremic syndrome: recognition of pancreatitis. J Pediatr Gastroenterol Nutr 1990, 11:518-524. 
20. Suri RS, Clark WF, Barrowman N, Mahon JL, Thiessen-Philbrook HR, RosasArellano MP, Zarnke K, Garland JS, Garg AX: Diabetes during diarrheaassociated hemolytic uremic syndrome: a systematic review and metaanalysis. Diabetes Care 2005, 28:2556-2562.

21. Gallo EG, Gianantonio CA: Extrarenal involvement in diarrhoea-associated haemolytic-uraemic syndrome. Pediatr Nephrol 1995, 9:117-119.

22. Kaplan BS, Meyers KE, Schulman SL: The pathogenesis and treatment of hemolytic uremic syndrome. J Am Soc Nephrol 1998, 9:1126-1133.

23. Noris M, Remuzzi G: Hemolytic uremic syndrome. J Am Soc Nephrol 2005, 16:1035-1050.

24. Grif K, Dierich MP, Karch H, Allerberger F: Strain-specific differences in the amount of Shiga toxin released from enterohemorrhagic Escherichia coli O157 following exposure to subinhibitory concentrations of antimicrobial agents. Eur J Clin Microbiol Infect Dis 1998, 17:761-766.

25. Kimmitt PT, Harwood CR, Barer MR: Toxin gene expression by shiga toxinproducing Escherichia coli: the role of antibiotics and the bacterial SOS response. Emerg Infect Dis 2000, 6:458-465.

26. Bell BP, Griffin PM, Lozano P, Christie DL, Kobayashi JM, Tarr PI: Predictors of hemolytic uremic syndrome in children during a large outbreak of Escherichia coli O157:H7 infections. Pediatrics 1997, 100:E12.

27. Brandt JR, Fouser LS, Watkins SL, Zelikovic I, Tarr PI, Nazar-Stewart V, Avner ED: Escherichia coli O 157:H7-associated hemolytic-uremic syndrome after ingestion of contaminated hamburgers. J Pediatr 1994, 125:519-526.

28. ProulX F, Sockett P: Prospective surveillance of Canadian children with the haemolytic uraemic syndrome. Pediatr Nephrol 2005, 20:786-790.

doi:10.1186/1757-7241-19-44

Cite this article as: Krogvold et al:: Clinical aspects of a nationwide epidemic of severe haemolytic uremic syndrome (HUS) in children. Scandinavian Journal of Trauma, Resuscitation and Emergency Medicine 2011 19:44.

\section{Submit your next manuscript to BioMed Central and take full advantage of:}

- Convenient online submission

- Thorough peer review

- No space constraints or color figure charges

- Immediate publication on acceptance

- Inclusion in PubMed, CAS, Scopus and Google Scholar

- Research which is freely available for redistribution

Submit your manuscript at www.biomedcentral.com/submit 